\title{
PLANT REGENERATION FROM COTYLEDONARY EXPLANTS OF Eucalyptus camaldulensis
}

\author{
Roberson Dibax ${ }^{1}$; Cristiane de Loyola Eisfeld ${ }^{2}$; Francine Lorena Cuquel $^{3}$; Henrique Koehler ${ }^{3}$; \\ Marguerite Quoirin ${ }^{2 *}$ \\ ${ }^{1}$ UFPR - Programa de Pós-Graduação em Agronomia. \\ ${ }_{3}^{2}$ UFPR - Depto. de Botânica, Setor de Ciências Biológicas, C.P. 19031 - 81531-990 - Curitiba, PR - Brasil. \\ ${ }^{3}$ UFPR - Depto. de Fitotecnia e Fitossanitarismo, Setor de Ciências Agrárias. \\ *Corresponding author <mquoirin@ufpr.br>
}

\begin{abstract}
Breeding methods based on genetic transformation techniques need to be implemented for Eucalyptus camaldulensis to shorten the long breeding cycles and avoid manipulation of adult trees; that requires the development of plant regeneration protocols enabling development of plants from transformed tissues. The present work aimed to optimise the regeneration process already established for the species. Cotyledonary leaves of $E$. camaldulensis were cultured in MS medium supplemented with naphthaleneacetic acid (NAA) and 6-benzylaminopurine (BAP) combinations. The most efficient treatment for bud indirect regeneration $\left(2.7 \mu \mathrm{mol} \mathrm{L}{ }^{-1} \mathrm{NAA}\right.$ and $\left.4.44 \mu \mathrm{mol} \mathrm{L}^{-1} \mathrm{BAP}\right)$ was used for further experiments. When explants were kept in the dark during the first 30 days, the percentage of explants forming calluses increased and explant necrosis was reduced in comparison with light-cultured explants. Mineral medium modifications were compared and half-strength MS mineral medium turned out to be as efficient as full-strength medium, producing $54 \%$ and $47 \%$ of explants with buds, respectively. For shoot elongation, MS medium with halfstrength nitrate and ammonium salts, and $0.2 \%$ activated charcoal yielded rooted shoots 1 to $8 \mathrm{~cm}$ high after one month. The procedure is an efficient protocol for E. camadulensis plant regeneration, reducing the stages necessary for the obtention of complete plants.
\end{abstract}

Key words: in vitro culture, forest species, culture media, organogenesis

\section{REGENERAÇÃO DE PLANTAS DE Eucalyptus camaldulensis A PARTIR DAS EXPLANTES COTILEDONARES}

\begin{abstract}
RESUMO: A implementação, para espécies florestais, de técnicas de melhoramento baseadas em métodos de transformação genética, permitirá reduzir os longos ciclos de melhoramento e evitar a manipulação de árvores adultas. Isto implica dispor de um protocolo de regeneração que permita o desenvolvimento de plantas a partir de tecidos transformados. Este trabalho teve como objetivo otimizar este protocolo de regeneração para Eucalyptus camaldulensis. Folhas cotiledonares foram cultivadas em meio de cultura MS suplementado com combinações de ácido naftalenoacético (ANA) e 6-benzilaminopurina (BAP). O tratamento mais eficiente em termos de regeneração indireta de gemas foi $2,7 \mu \mathrm{mol} \mathrm{L}^{-1}$ de ANA combinado com $4,44 \mu \mathrm{mol} \mathrm{L}^{-1}$ de BAP, o qual foi utilizado nos experimentos posteriores. A manutenção dos explantes no escuro durante os trinta primeiros dias elevou a porcentagem de explantes com calos e reduziu a morte dos explantes, em comparação com os que permaneceram na luz. Modificações da composição mineral do meio MS foram comparadas e mostraram que a redução de metade dos sais foi tão eficiente para a formação de gemas (54\% dos explantes) quanto o meio completo (47\%). O meio de cultura com a concentração de íons nitrato e amônio reduzida à metade e $0,2 \%$ de carvão ativado apresentou-se adequado para o alongamento e enraizamento das brotações que atingiram uma altura de 1 a $8 \mathrm{~cm}$ depois de 30 dias. O processo completo representa um protocolo eficiente para a regeneração de plantas de Eucalyptus camaldulensis, uma vez que reduz o número de etapas para a obtenção de plantas completas.

Palavras-chave: cultura in vitro, espécies florestais, meios de cultura, organogênese
\end{abstract}

\section{INTRODUCTION}

Eucalyptus camaldulensis, (Myrtaceae) has high potential for adaptation to Brazilian tropical conditions (Rizzini, 1971). Although its wood is not recommended for cellulose and paper pulp industry, it is an excellent alternative for furniture manufacturing, building and energy production (Rizzini, 1971; Souza, 2001).

Breeding methods based on genetic transformation techniques need to be developed for this species to shorten the long breeding cycles and avoid manipulation of adult trees. The establishment of plant regeneration 
protocols will allow plants to be developed from transformed tissues.

According to Ho et al. (1998), a MS based medium (Murashige \& Skoog, 1962) supplemented with naphthalenacetic acid (NAA) $\left(16.2 \mu \mathrm{mol} \mathrm{L}^{-1}\right)$ and 6benzylaminopurine (BAP) $\left(4.44 \mu \mathrm{mol} \mathrm{L}^{-1}\right)$ can be used for induction of callus and bud regeneration in $E$. camaldulensis. Mullins et al. (1997) also succeeded in regenerating E. camaldulensis buds from leaf explants of in vitro-cultured plants. The culture medium used was an adaptation of Muralidharan \& Mascarenhas (1987) medium, supplemented with $1.0 \mathrm{~g} \mathrm{~L}^{-1}$ casein, $16.2 \mu \mathrm{mol} \mathrm{L}^{-1} \mathrm{NAA}$, $0.44 \mu \mathrm{mol} \mathrm{L}^{-1} \mathrm{BAP}, 50 \mathrm{~g} \mathrm{~L}^{-1}(\mathrm{w} / \mathrm{v})$ sucrose and $0.5 \%(\mathrm{w} / \mathrm{v})$ Phytagar $^{\circledR}$. Arezki et al. (2000) observed the proliferation of meristematic agglomerates in E. camaldulensis explants cultured on MAS culture medium [MS medium containing $5 \mu \mathrm{mol} \mathrm{L}{ }^{-1}$ indolebutyric acid, $30 \mathrm{~g} \mathrm{~L}^{-1}(\mathrm{w} / \mathrm{v})$ sucrose, $0.5 \%(\mathrm{w} / \mathrm{v})$ agar and $0.2 \%(\mathrm{w} / \mathrm{v})$ activated charcoal]. Diallo \& Duhoux (1984) obtained plant regeneration from cotyledonary leaves of the same species using MS medium supplemented with NAA, BAP and $20 \mathrm{~g} \mathrm{~L}^{-1}(\mathrm{w} / \mathrm{v})$ sucrose. Valério et al. (2003) reported a process of shoot regeneration from young leaves on LS (Linsmaier \& Skoog, 1965) medium, used for genetic transformation of this species. This study describes a procedure of adventitious bud regeneration from cotyledonary leaves of E. camaldulensis and subsequent development of rooted shoots.

\section{MATERIAL AND METHODS}

\section{Plant material and seed germination}

Seeds of Eucalyptus camaldulensis, collected in Itabé, SP, Brazil, were provided by the Instituto de Pesquisas Florestais (IPEF, Piracicaba, SP, Brazil). Seeds were surface-sterilized by immersion in $70 \%(\mathrm{v} / \mathrm{v})$ ethanol for two minutes, and later in sodium hypochlorite $6 \%$ $(\mathrm{v} / \mathrm{v})$ containing Tween ${ }^{\circledR} 20(5$ drops in $100 \mathrm{~mL})$ for 20 minutes. Seeds were then rinsed three times in sterile distilled water. Germination medium consisted of halfstrength MS mineral salts, MS vitamins and organic compounds, $20 \mathrm{~g} \mathrm{~L}^{-1}$ sucrose, and $7 \mathrm{~g} \mathrm{~L}^{-1}$ agar $\left(\operatorname{Vetec}^{\circledR}\right), \mathrm{pH}$ of 5.8. The culture medium was autoclaved at $120^{\circ} \mathrm{C}$ for $20 \mathrm{~min}$, and poured into Petri dishes $(10 \mathrm{~cm} \varnothing \times 2 \mathrm{~cm}$ high) sealed with PVC film. Seeds were then sown in a laminar flow cabinet.

\section{In vitro culture conditions and culture media}

Cultures were maintained in a growth chamber under cold, white fluorescent light, with a photon flux density of approximately $40 \mu \mathrm{mol} \mathrm{m} \mathrm{m}^{-2}, 16 / 8$ light/dark regime, $27 \pm 2^{\circ} \mathrm{C}$. Basal culture medium was MS medium with $30 \mathrm{~g} \mathrm{~L}^{-1}(\mathrm{w} / \mathrm{v})$ sucrose and $7 \mathrm{~g} \mathrm{~L}^{-1}(\mathrm{w} / \mathrm{v})$ agar $\left(\operatorname{Vetec}^{\mathbb{B}}\right)$, $\mathrm{pH}$ 5.8. All media were autoclaved as described above, and except for seed germination, poured into flasks (60 $\mathrm{mm} \varnothing \times 90 \mathrm{~mm}$ high) covered with plastic cap.

\section{Indirect organogenesis}

Fifteen days after sowing, cotyledonary leaves were excised at the petiole base and cultured with the adaxial face in contact with culture medium. In the first experiment, nine treatments were tested, consisting of the combinations of $0,2.7$ and $5.4 \mu \mathrm{mol} \mathrm{L}^{-1} \mathrm{NAA}$ with $0,4.44$ and $13.32 \mu \mathrm{mol} \mathrm{L}^{-1} \mathrm{BAP}$, in a totally randomised experimental design, $3 \times 3$ factorial scheme $(\mathrm{n}=15)$.

To test for the effect of absence of light, the two combinations of growth regulators yielding the best regeneration results $\left(2.7\right.$ or $5.4 \mu \mathrm{mol} \mathrm{L}{ }^{-1} \mathrm{NAA}$ and 4.44 $\left.\mu \mathrm{mol} \mathrm{L}{ }^{-1} \mathrm{BAP}\right)$ were used and compared with a control medium without growth regulators, with half the cultures kept in the light in a totally randomised, experimental design, $3 \times 2$ factorial scheme $(n=15)$. The following modifications of MS mineral salt composition were also tested: (1) half-strength MS mineral medium, (2) half-strength MS macronutrients and (3) half-strength MS potassium and ammonium nitrates.

Another trial tested three treatments 30 days after explant inoculation. First, explants were cultured on MS medium containing $2.7 \mu \mathrm{mol} \mathrm{L}^{-1} \mathrm{NAA}$ and $4.44 \mu \mathrm{mol}$ $\mathrm{L}^{-1} \mathrm{BAP}$ for 30 days. Then, one third of them were transferred to the same medium, fresh (Treatment 1); one third remained on the initial medium for additional 30 days (Treatment 2), and the last part was transferred to a medium without growth regulators (Treatment 3 ). After 30 days, the percentage of explants forming calluses and their colour were evaluated for each treatment; after 60 days the percentage of explants that regenerated buds, the number of buds per explant and percentage of dead explants were recorded. Experimental design was totally randomised, with 15 replicates per treatment and 8 explants per flask.

Values used for statistical analyses were the means obtained from three experiments. Treatment effects were analysed by ANOVA and means compared by Tukey's multiple range test using MSTATC (Michigan State University) program $(\alpha=0.05)$. For some results, a second degree polynomial model was fitted. The adjusted equation model was: $\mathrm{Y}=\mathrm{b}_{\mathrm{o}}+\mathrm{b}_{1} \mathrm{X}+\mathrm{b}_{2} \mathrm{X}^{2}$ where $Y$ was the variable, $X$ the applied treatment, and $b_{0}, b_{1}$, $\mathrm{b}_{2}$ the coefficients of the model.

\section{Elongation and rooting}

Buds obtained on MS medium containing 2.7 $\mu \mathrm{mol} \mathrm{L}{ }^{-1} \mathrm{NAA}$ and $4.44 \mu \mathrm{mol} \mathrm{L}^{-1}$ BAP were submitted to two treatments for elongation and rooting: (1) MS medium, (2) MS medium with half-strength nitrates and $0.2 \%(\mathrm{w} / \mathrm{v})$ activated charcoal. Each treatment consisted of 12 replicates with two explants of $0.5 \mathrm{~cm}$ in each flask. At 60 days of growth, root number and size were recorded, as well as the presence of calluses on leaves. 


\section{RESULTS AND DISCUSSION}

Effect of the combinations of NAA and BAP on callogenesis and regeneration from cotyledonary leaves of $E$. camaldulensis

All treatments with BAP alone, or NAA and BAP combinations, efficiently induced callogenesis (Figure 1A). For 0 and $2.7 \mu \mathrm{mol} \mathrm{L}^{-1} \mathrm{NAA}$, both concentrations of BAP were efficient, without differences among the results. The combinations $5.4 \mu \mathrm{mol} \mathrm{L}^{-1} \mathrm{NAA}$ and $4.44 \mu \mathrm{mol}$ $\mathrm{L}^{-1} \mathrm{BAP}$ or $2.7 \mu \mathrm{mol} \mathrm{L}^{-1} \mathrm{NAA}$ and $13.32 \mu \mathrm{mol} \mathrm{L}^{-1} \mathrm{BAP}$ induced callogenesis in $90 \%$ of the explants (Figure 1A). Calluses beared different colours associated to the presence of anthocyanins, and buds sprouted from greenish and red calluses, in the petiole region after 60 days. The base of the petiole was the best region for callogenesis and subsequent bud formation (Figure 2), probably because of the accumulation of photosynthesis products in the region, or to the polar transport of growth regulators (Margara, 1982). Results confirm those obtained by Muralidharan \& Mascarenhas (1987) and Hervé et al.
(2001), who observed a correlation between the formation of red calluses and the regeneration of adventitious buds at distal part of the petiole of foliar explants of $E$. camaldulensis and E. gunnii, respectively.

Regarding the percentage of explants regenerating buds and number of buds per explant, the interaction among NAA and BAP concentrations was not significant. Among the combinations of the tested growth substances, those of 2.7 or $5.4 \mu \mathrm{mol} \mathrm{L}{ }^{-1} \mathrm{NAA}$ and 4.44 $\mu$ mol L ${ }^{-1}$ BAP yielded best results (Figure 1B and C); regression curves indicated optimum values when the concentration of BAP was between 4.44 and $8.88 \mu \mathrm{mol}$ $\mathrm{L}^{-1}$. These results differ from those described by Ho et al. (1998) and Diallo \& Duhoux (1984), who obtained bud regeneration on cotyledonary leaf explants cultured in the presence of $16.2 \mu \mathrm{mol} \mathrm{L}^{-1} \mathrm{NAA}$ and $4.44 \mu \mathrm{mol}$ $\mathrm{L}^{-1} \mathrm{BAP}$ or $5.4 \mu \mathrm{mol} \mathrm{L}^{-1} \mathrm{NAA}$ and $2.22 \mu \mathrm{mol} \mathrm{L}^{-1} \mathrm{BAP}$. These authors used auxin concentration higher than the BAP concentration. In this study, best results were obtained when concentration of BAP was superior to concentration of NAA.
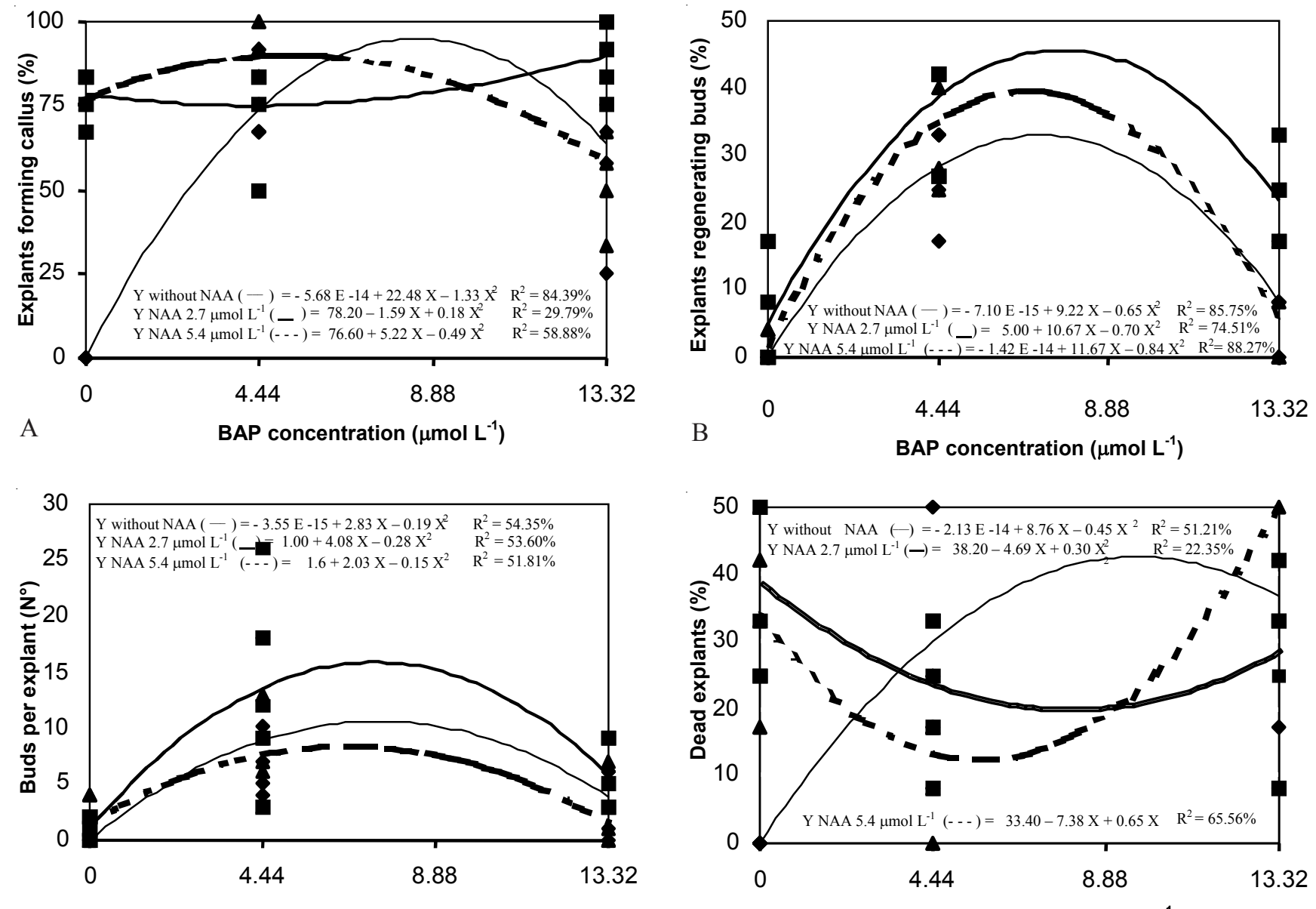

C

BAP concentration ( $\left.\mu \mathrm{mol} \mathrm{L}^{-1}\right)$

D

BAP concentration $\left(\mu \mathrm{mol} \mathrm{L^{-1 } )}\right.$

Figure 1 - Effect of combinations of NAA and BAP (A) on callogenesis after 30 days, (B and C) on formation of adventitious buds and (D) on necrosis after 60 days, for cotyledon explants of Eucalyptus camaldulensis. 

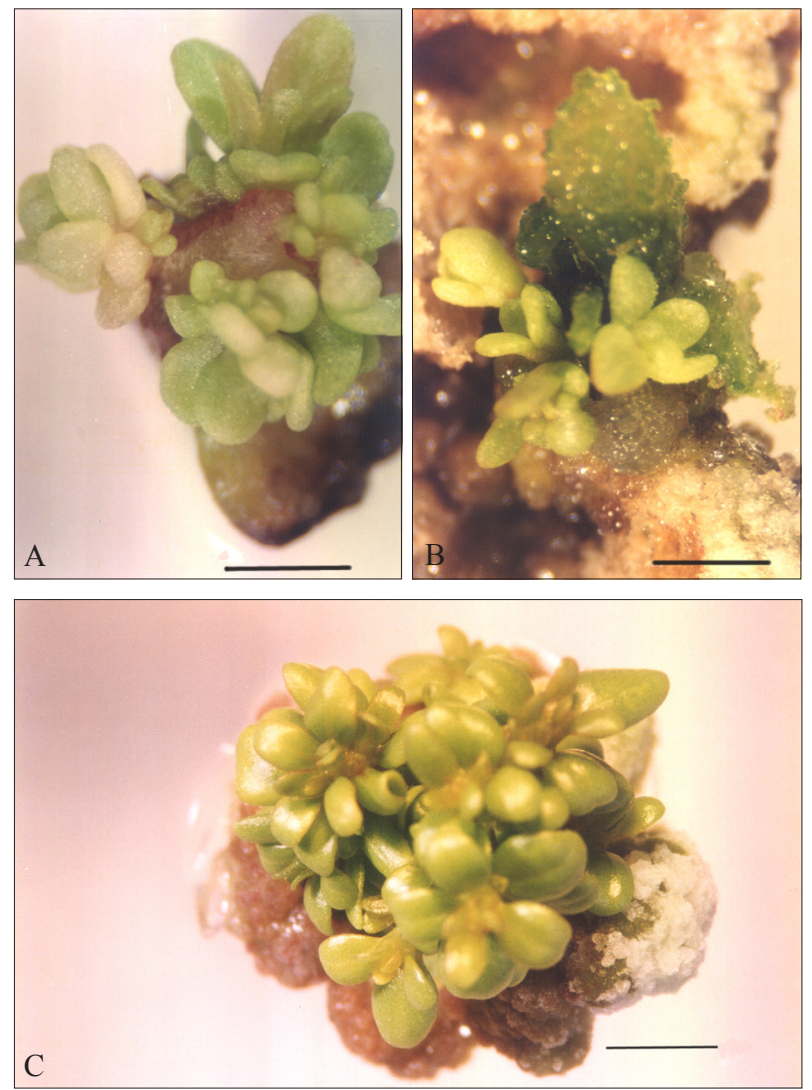

Figure 2 - Effect of NAA and BAP combinations on bud regeneration from cotyledonary leaves of Eucalyptus camaldulensis. (A) Bud formation after 30 days of culture on MS medium containing $2.7 \mu \mathrm{mol} \mathrm{L}^{-1} \mathrm{NAA}$. Bar $=2.3 \mathrm{~mm}$. (B) Petiole base showing bud formation after 15 days of culture on MS medium containing 5.4 $\mu \mathrm{mol} \mathrm{L}{ }^{-1}$ NAA and $4.44 \mu \mathrm{mol} \mathrm{L}^{-1}$ BAP. Bar $=1.25$ mm. (C) Clump of buds covering the explant after 60 days of culture on MS medium containing $2.7 \mu \mathrm{mol} \mathrm{L}^{-1}$ NAA and $4.44 \mu \mathrm{mol} \mathrm{L}^{-1}$ BAP. Bar $=2.2 \mathrm{~mm}$.

According to Tibok et al. (1995), different results of bud regeneration in the same kind of explant may result from genotypic variation among seeds used for explant production. However, our observations are in accordance with those of Skoog \& Miller (1956), who were the first to indicate that the process of bud neoformation requires a hormonal balance between auxin and cytokinin that favours cytokinin. In a study with $E$. grandis $\times$ E. urophylla leaves, Barrueto Cid et al. (1999) obtained callus induction when the explants were cultured in the presence of $20 \mu \mathrm{mol} \mathrm{L}^{-1}$ thidiazuron and bud formation with $5 \mu \mathrm{mol} \mathrm{L}{ }^{-1}$ BAP and $0.5 \mu \mathrm{mol} \mathrm{L}^{-1}$ NAA. The highest regeneration percentages were reported by these authors for leaf explants of 30 and 40 days (53\%), in comparison with explants of 20 and 50 days (13\%). In our case, only 30-day-old explants were used, and regeneration was $33.9 \%$.

Explant necrosis was reduced by addition of BAP (4.44 to $8.88 \mu \mathrm{mol} \mathrm{L}^{-1}$ ) when NAA was present, but it was increased by this cytokinin in the absence of the auxin. The lowest value was reached with the combination of $5.4 \mu \mathrm{mol} \mathrm{L}^{-1} \mathrm{NAA}$ and $4.44 \mu \mathrm{mol} \mathrm{L}^{-1}$ BAP. Barrueto Cid et al. (1999) also observed the oxidation of the explants of E. grandis $\times E$. urophylla cultured for more than 8 weeks in regeneration medium, and related this result to the activation of specific promoters involved in the biosynthesis of phenolic compounds by light.

\section{Effect of the absence of light during callogenesis and bud regeneration}

For all combinations of growth regulators tested, the highest percentages of explants with calluses (90.2\%) for both NAA concentrations were obtained when the explants were kept in the dark for 30 days (Figure 3A). An initial treatment of the explants in darkness for 30 days was beneficial for callus formation from cotyledons of the hybrid $E$. grandis $\times E$. urophylla (Gonzáles et al., 2002). Also according to Warrag et al. (1991), a period of four weeks in the dark promoted callogenesis for E. urophylla explants (immature inflorescences or parts of them, zygotic embryos and hypocotyls).

Regarding the percentage of explants that regenerated buds, there were no interactions between the levels of growth regulators and light conditions of the culture. All treatments were efficient in inducing bud regeneration and the best percentage of regeneration (39.2\%) was attained when explants were cultured in the dark, on culture medium containing $5.4 \mu \mathrm{mol} \mathrm{L}{ }^{-1} \mathrm{NAA}$ and 4.44 $\mu \mathrm{mol} \mathrm{L}{ }^{-1}$ BAP (Figure 3B). The number of buds per explant - 3.8 to 4.6 buds - did not differ among the treatments (Figure 3C). Dark conditions for 30 days reduced explant necrosis (Figure 3D). The induction of tissue necrosis by light was also observed by Lainé \& David (1994), who studying callogenesis and bud regeneration from $E$. grandis leaves, demonstrated that dark condition is beneficial at the beginning of the culture, for it reduces negative effects caused by the exsudation of phenolic compounds and, consequently, reduces explant necrosis, even without using PVP or antioxidants. The percentage of callus-developing buds, after an initial period of culture under dark and posterior exposition to light, was $38.5 \%$; for those maintained under light, $7.1 \%$.

\section{Effect of modifications of MS mineral content on callogenesis and bud regeneration}

Results did not differ when the concentration of MS mineral medium was modified (Table 1), except for the percentage of necrosis, which was slightly lower on a medium with half-strength MS salts. All treatments yielded percentages of regeneration between 44 and 54\%, the average number of buds per explant varying between 7 and 13. The modifications of mineral composition of the culture medium, especially nitrogen compounds, were not important for the regeneration process. Valério et al. (2003) described a protocol for bud regeneration from 
Table 1 - Effect of modifications of MS mineral composition on callogenesis and bud regeneration from cotyledonary explants of Eucalyptus camaldulensis.

\begin{tabular}{lcccc}
\hline Treatment & $\begin{array}{c}\text { Explants with } \\
\text { callus }\end{array}$ & $\begin{array}{c}\text { Explants with } \\
\text { buds }\end{array}$ & $\begin{array}{c}\text { Dead } \\
\text { explants }\end{array}$ & $\begin{array}{c}\text { Mean number of buds } \\
\text { per explant }\end{array}$ \\
\hline & $86.68 \mathrm{a}$ & $46.68 \mathrm{a}$ & $8.34 \mathrm{ab}$ & $13.0 \mathrm{a}$ \\
MS medium & $87.78 \mathrm{a}$ & $54.08 \mathrm{a}$ & $2.40 \mathrm{~b}$ & $9.0 \mathrm{a}$ \\
$1 / 2$ MS salts & $97.40 \mathrm{a}$ & $50.80 \mathrm{a}$ & $11.68 \mathrm{a}$ & $7.0 \mathrm{a}$ \\
$1 / 2$ MS macronutrients & $97.50 \mathrm{a}$ & $44.30 \mathrm{a}$ & $5.0 \mathrm{ab}$ & $9.0 \mathrm{a}$ \\
$1 / 2$ MS nitrate salts & 10.92 & 19.81 & 72.87 & 41.48 \\
\hline Coefficient of variation $(\%)$ & & & \\
\hline
\end{tabular}

Means followed by the same letter in a column do not differ by $(P<0.05)$ Tukey's multiple range test.

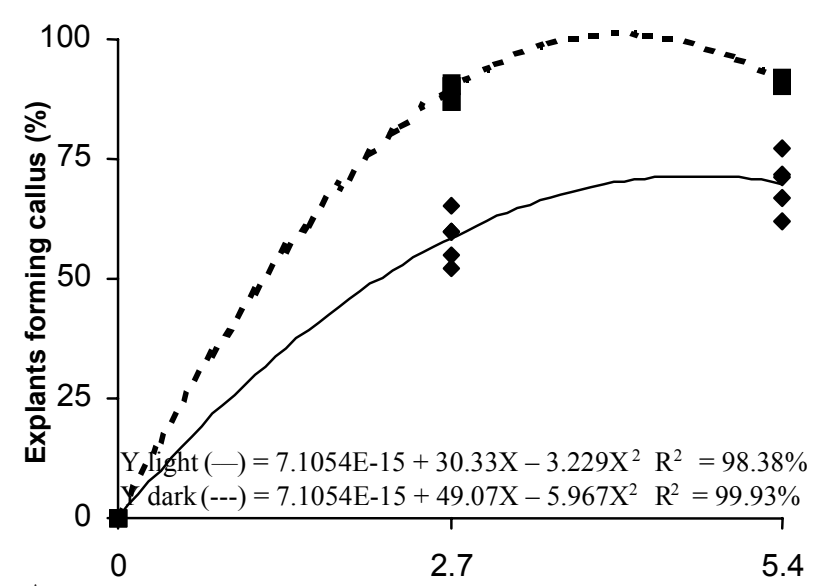

A

NAA concentration $\left(\mu \mathrm{mol} \mathrm{L}{ }^{-1}\right)$

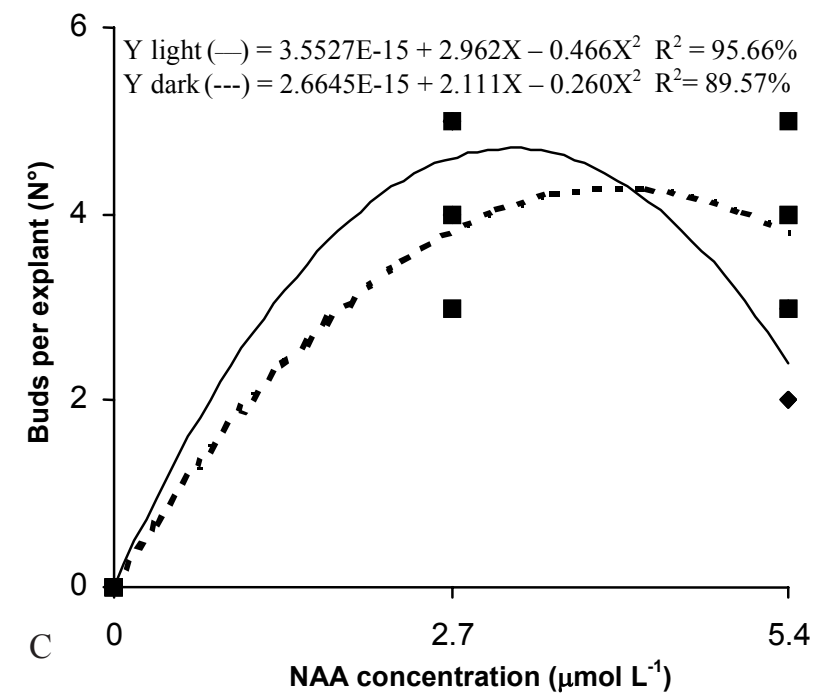

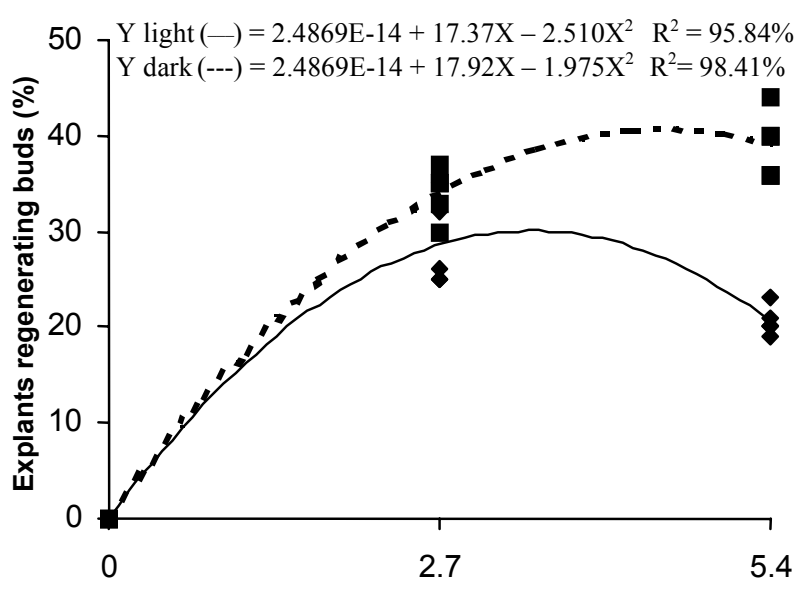

B

NAA concentration $\left(\mu \mathrm{mol} L^{-1}\right)$

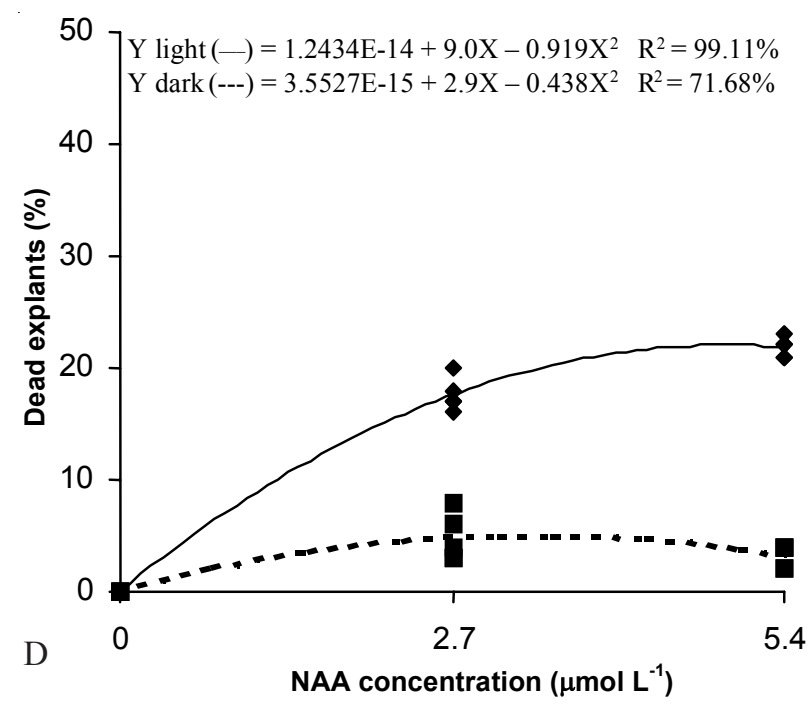

Figure 3 - Effect of light and dark treatments (A) on callogenesis after 30 days, (B and C) on adventitious bud regeneration and (D) on necrosis after 60 days for cotyledon explants of Eucalyptus camaldulensis cultured on MS medium supplemented with 4.44 $\mu \mathrm{mol} \mathrm{L} \mathrm{L}^{-1} \mathrm{BAP}$ and several concentrations of NAA.

young leaves of the same species where Linsmaier \& Skoog (1965) medium was used, while Moralejo et al. (1998) recommended the Woody Plant Medium of Lloyd \& McCown (1981) for E. globulus. Both media present a reduction of salt concentration when compared to MS medium.

\section{Effect of duration of culture on MS medium supple-} mented with auxin and cytokinin

All treatments were equally efficient in inducing callogenesis (Table 2). The highest mean percentage of explants that differentiate into buds $(51.5 \%)$ and lowest necrosis level $(3.2 \%)$ were recorded when the explants 
Table 2 - Effect of duration of culture on MS medium supplemented with $2.7 \mu \mathrm{mol} \mathrm{L}^{-1} \mathrm{NAA}$ and $4.44 \mu \mathrm{mol} \mathrm{L} \mathrm{L}^{-1} \mathrm{BAP}$ on callogenesis, bud formation and necrosis of Eucalyptus camaldulensis cotyledonary explants.

\begin{tabular}{lcccc}
\hline Treatment & $\begin{array}{c}\text { Explants with } \\
\text { callus }\end{array}$ & $\begin{array}{c}\text { Explants with } \\
\text { buds }\end{array}$ & $\begin{array}{c}\text { Dead } \\
\text { explants }\end{array}$ & $\begin{array}{c}\text { Mean number of buds } \\
\text { per explant }\end{array}$ \\
\hline 1 & $98.24 \mathrm{a}$ & $45.80 \mathrm{ab}$ & $5.56 \mathrm{~b}$ & $11.80 \mathrm{a}$ \\
2 & $100.00 \mathrm{a}$ & $31.60 \mathrm{~b}$ & $24.10 \mathrm{a}$ & $4.40 \mathrm{~b}$ \\
3 & $100.00 \mathrm{a}$ & $51.50 \mathrm{a}$ & $3.20 \mathrm{~b}$ & $8.20 \mathrm{ab}$ \\
\hline Coefficient of variation $(\%)$ & 1.56 & 21.47 & 89.07 & 39.94 \\
\hline
\end{tabular}

Means followed by the same letter in a column do not differ $(P<0.05)$ Tukey's multiple range test. 1: Explants transferred to the same medium after 30 days; 2: Explants maintained on this medium for 60 days; 3: Explants transferred to a medium without growth regulators after 30 days.

were transferred to a medium without growth regulators after 30 days (treatment 3 ), but these values did not differ from those obtained when the explants were subcultured on the same medium (treatment 1). The mean number of buds per explant was higher after treatment 1 or on a medium without growth regulators (treatment 3 ). Necrosis of the explants increased when they remained in the same medium for 60 days (treatment 2), possibly as a result of death of tissues caused by the release of phenolic compounds by the explants.

\section{Shoot elongation and rooting}

Buds transferred to MS medium without activated charcoal and growth substances produced chlorotic plantlets. Elongation was not uniform and no root was formed. The exsudation of phenolic compounds into the medium was observed. This phenomenon had already been described by Lainé \& David (1994) during the regeneration process from E. grandis leaves. According to these authors, the negative effects caused by the liberation of phenolic compounds may be minimized with the addition of PVP or other antioxydants to the culture medium. Another solution consists in keeping the explants in the dark for five days (Valério et al., 2003).

Buds submitted to the second treatment ( $1 / 2 \mathrm{ni}-$ trates and activated charcoal) elongated and no symptom of leaf chlorosis appeared. Plantlets were between 1.0 and $8.0 \mathrm{~cm}$ high, their leaves were dark green and covered with calluses, and eight roots were formed in average per plant, with a mean size of $10 \mathrm{~cm}$. These results are in accordance with those obtained by Gupta et al. (1993), who reported that activated charcoal stimulates rooting in E. torelliana and E. camaldulensis shoots.

Rodrigues \& Vendrame (2003) indicated that the efficiency of eucalyptus micropropagation is highly dependent of the ionic balance of culture medium. For example, the JADS medium (Correia, 1993; Correia et al., 1995) was developed to meet the nutritional requirements of young plantlets of E. grandis. This medium, specific for eucalyptus, is characterised by significant reduction of nitrogen compounds and other mineral salts, in comparison to MS culture medium. Tournier et al. (2003) also described culture media with nutritive balances specific for each stage of the regeneration process and adapted for the hybrid $E$. grandis $\times E$. urophylla.

Several aspects of the described procedure made it cheaper than others published for this species: reduction of salt content of MS medium, suppression of growth regulators during elongation and rooting, which occurred in one stage only. Acclimatisation studies need to be developed to complement the present study. Histological studies are underway to determine the origin of adventitious buds.

\section{ACKNOWLEDGMENTS}

To the Instituto de Pesquisas Florestais (IPEF), Piracicaba, SP, Brazil, for providing seeds and to the Laboratório de Micropropagação de Plantas, Departamento de Fitotecnia e Fitossanitarismo, Setor de Ciências Agrárias, Universidade Federal do Paraná, for use of equipment and reagents. To Coordenação de Aperfeiçoamento de Pessoal de Nível Superior (CAPES), Brazil, for a grant to the first author.

\section{REFERENCES}

AREZKI, O.; BOXUS, P.; KEVERS, C.; GASPAR, T. Hormonal control of proliferation in meristematic agglomerates of Eucalyptus camaldulensis DEHN. In Vitro Cellular \& Developmental Biology - Plant, v.36, p.398-401, 2000.

BARRUETO CID, L.P.; MACHADO, A.C.M.; CARVALHEIRA, S.R.C.; BRASILEIRO, A.C.M. Plant regeneration from seedling explants of Eucalyptus grandis ' E. urophylla. Plant Cell, Tissue and Organ Culture, v.56, p.17-23, 1999.

CORREIA, D. Crescimento e desenvolvimento de gemas na multiplicação de Eucalyptus spp. em meio de cultura líquido e sólido. Piracicaba: USP/ ESALQ 1993.113p. (Dissertação - Mestrado).

CORREIA, D.; GONÇALVES, A.N.; COUTO, H.T.Z. do; RIBEIRO, M.C. Efeito do meio de cultura líquido e sólido no crescimento e desenvolvimento de Eucalyptus grandis ' Eucalyptus urophylla na multiplicação in vitro. IPEF, v.48/49, p.107-116, 1995.

DIALLO, N.; DUHOUX, E. Organogenèse et multiplication "in vitro" chez 1'Eucalyptus camaldulensis. Journal of Plant Physiology, v.115, p.177182,1984 
GONZÁLES, E.R.; ANDRADE, A.; BERTOLO, A.L.; LACERDA, G.C.; CARNEIRO, R.T.; DEFÁVARI, V.; VENEZIANO LABATE, M.; LABATE, C.A. Production of transgenic Eucalyptus grandis $\times$ urophylla using the sonication-assisted Agrobacterium transformation (SAAT) system. Functional Plant Biology, v.29, p.97-102, 2002.

GUPTA, P.K.; MEHTA, U.J.; MASCARENHAS, A.F. A tissue culture method for rapid clonal propagation of mature trees of Eucalyptus torelliana and Eucalyptus camaldulensis. Plant Cell Reports, v.2, p.296299, 1993.

HERVÉ, P.; JAUNEAU, A.; PÂQUES, M.; MARIEN, J.N.; BOUDET, A.M.; TEULIÈRES, C. A procedure for shoot organogenesis in vitro from leaves and nodes of an elite Eucalyptus gunnii clone: comparative histology. Plant Science, v.161, p.645-653, 2001.

HO, C.K.; CHANG, S.H.; TSAY, J.Y.; TSAI, C.J.; CHIANG, V.L.; CHEN, Z.Z. Agrobacterium tumefaciens-mediated transformation of Eucalyptus camaldulensis and production of transgenic plants. Plant Cell Reports, v.17, p.675-680, 1998.

LAINÉ, E.; DAVID, A. Regeneration of plants from leaf explants of micropropagated clonal Eucalyptus grandis. Plant Cell Reports, v.13, p.473-476, 1994.

LINSMAIER, E.M.; SKOOG, F. Organic growth factor requirement of tobacco tissue cultures. Physiologia Plantarum, v.18, p.100-127, 1965.

LLOYD, G.; McCOWN, B. Commercially-feasible micropropagation of mountain laurel, Kalmia latifolia, by use of shoot-tip culture. Combined Proceedings International Plant Propagators Society, v.30, p.421427, 1981.

MARGARA, J. Bases de la multiplication végétative. Paris: Institut National de la Recherche Agronomique, 1982. 60p.

MORALEJO, M.; ROCHANGE, F.; BOUDET, A.M.; TEULIERES, C. Generation of transgenic Eucalyptus globulus plantlets through Agrobacterium tumefaciens mediated transformation. Australian Journal of Plant Physiology, v.25, p.207-212, 1998.

MULLINS, K.V.; LLEWELLYN, D.J.; HARTNEY, V.J.; STRAUSS, S; DENNIS, S. E. Regeneration and transformation of Eucalyptus camaldulensis. Plant Cell Reports, v.16, p.787-791, 1997.

MURALIDHARAN, E.M.; MASCARENHAS, A.F. In vitro plantlet formation by organogenesis in Eucalyptus camaldulensis and by somatic embryogenesis in Eucalyptus citriodora. Plant Cell Reports, v.6, p.256259, 1987.
MURASHIGE, T.; SKOOG, F. A revised medium for rapid growth and bioassays with tobacco tissue cultures. Physiologia Plantarum, v.15, p.473-497, 1962.

RIZZINI, C.T. Árvores e madeiras úteis do Brasil. 2.ed. São Paulo: Ed. Edgard Blücher, 1971.

RODRIGUES, A.P.M.; VENDRAME, W.A. Micropropagation of tropical woody species. In: JAIN, S.M.; ISHII, K. (Ed.) Micropropagation of woody trees and fruits. Dordrecht: Kluwer Academic Publishers, 2003. p.157-158. (Forestry Sciences, 75).

SKOOG, F.; MILLER, C. Chemical regulation of growth and organ formation in plant tissues cultivated in vitro. Symposium of the Society of Experimental Botany, v.9, p.118-131, 1956.

SOUZA, J.A. O potencial da silvicultura na Amazônia. Revista Silvicultura, v.80, 1999. Disponível em: <http:/www.sbc.org.br/revista/revistacelmar.html>. Acesso em: 12 set. 2001.

TIBOK, A.; BLACKHALL, N.W.; POWER, J.B.; DAVEY, M.R. Optimised plant regeneration from callus derived from seedling hypocotyls of Eucalyptus urophylla. Plant Science, v.110, p.139-145, 1995.

TOURNIER, V.; GRAT, S.; MARQUE, C.; EL KAYAL, W.; PENCHEL, R.; ANDRADE, G. de; BOUDET, A.-M.; TEULIÈRES, C. An efficient procedure to stably introduce genes into an economically important pulp tree (Eucalyptus grandis $\times$ Eucalyptus urophylla). Transgenic Research, v.12, p.403-411, 2003.

VALÉRIO, L.; CARTER, D.; RODRIGUES, J.C.; TOURNIER, V.; GOMINHO, J.; MARQUE, C.; BOUDET, A.-M.; MAUNDERS, M.; PEREIRA, H.; TEULIÈRES, C. Down regulation of cinnamyl alcohol dehydrogenase, a lignification enzyme, in Eucalyptus camaldulensis. Molecular Breeding, v.12, p.157-167, 2003.

WARRAG, E.; LESLEY, M.S.; ROCKWOOD, D.J. Nodule culture and regeneration of Eucalyptus grandis hybrids. Plant Cell Reports, v.9, p.586-589, 1991.

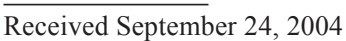

Accepted June 14, 2005 